\title{
Diógenes, população de rua, luta antimanicomial e cinismo
}

\author{
Diogenes, homeless population, \\ antimanicomial movement and cinism
}

\begin{abstract}
Sr. Editor,
A imprensa tem noticiado um fenômeno intrigante no qual idosos optam por viver como mendigos nas ruas, em péssimas condições de higiene, acumulando bugigangas e recusando auxílio de órgãos governamentais. ${ }^{1}$ Estes últimos jamais cogitam a possibilidade de se tratar de um distúrbio psiquiátrico, porque na sua ingênua (ou nem tanto) ignorância, parecem desconhecer a Síndrome de Diógenes. Reconhecida como uma doença da terceira idade e batizada com o nome do importante filósofo grego e fundador da escola cínica, ele vivia como mendigo e dormia em um barril. A síndrome é caracterizada justamente por descuidos com a higiene pessoal e/ou com o asseio da própria moradia e pela opção de viver nas ruas, mesmo quando poderiam viver em melhores instalações, seja pela condição financeira que detêm, seja porque muitos dispõem de famílias que desejam recebê-los de volta, ou pela oferta de alternativas dos órgãos responsáveis - (abrigos, casas de saúde), suspeição e comportamento paranóico (desconfiam do assédio de pessoas que queiram oferecer auxílio e não gostam de falar sobre suas condições de vida) e, finalmente, a siligomania. ${ }^{2-4}$ Esta última característica assume a forma de colecionismo (acúmulo de quantidade apreciável de objetos inúteis, já descartados, sem um propósito aparente ${ }^{5}$ ), podendo atingir proporções surpreendentes (um caso recentemente noticiado na Folha de São Paulo ${ }^{1}$ acumulou nada mais que 52 caminhões de lixo em seu sobrado!).
\end{abstract}

Estes casos servem para registrar o desprezo e a incompetência técnica de que os órgãos públicos padecem diante das doenças médicas do sistema nervoso central, na medida em que relegam estes doentes às ruas, privando-os de adequado atendimento médico psiquiátrico, com diagnóstico e tratamento específicos. Mas é óbvio que isto custa caro. Óbvio também que os governos preferem não vê-los e nem reconhecê-los como doentes, deixando-os na invisível e confortável condição de anômicos que fazem parte de nossas paisagens urbanas sem causar-nos sensação. Quando muito se tornam notícia de jornal pelas suas bizarrices. A luta antimanicomial apenas trocou de cenários; trocaram os depósitos de pacientes dos hospícios pelos depósitos nas ruas. Viva o cinismo! Viva Diógenes!

Leonardo Caixeta

Universidade Federal de Goiás (UFG), Goiânia (GO), Brasil

Financinamento: Inexistente

Conflito de interesses: Inexistente

Referências

1. [Sem autor]. Idosa impede retirada de lixo de sua casa. Folha de $S$. Paulo. São Paulo. 2006 jul 12.

2. Macmillan D, Shaw P. Senile breakdown in standards of personal and environmental cleanliness. Br Med J. 1966;29(5521):1032-7.

3. Radebaugh TS, Hooper FJ, Gruenberg EM. The social breakdown syndrome in the elderly population living in the community: the helping study. Br J Psychiatry. 1987;151:341-6.

4. Roe PF. Self-neglect. Age Ageing. 1977;6:192-4.

5. Clark AN, Mankikar GD, Gray I. Diogenes syndrome. A clinical study of gross neglect in old age. Lancet. 1975;1(7903):366-8. 